\title{
The leadership challenges of Paul's collection for the saints in Jerusalem: Part I: Overcoming the obstacles on the side of the Gentile Christian donors
}

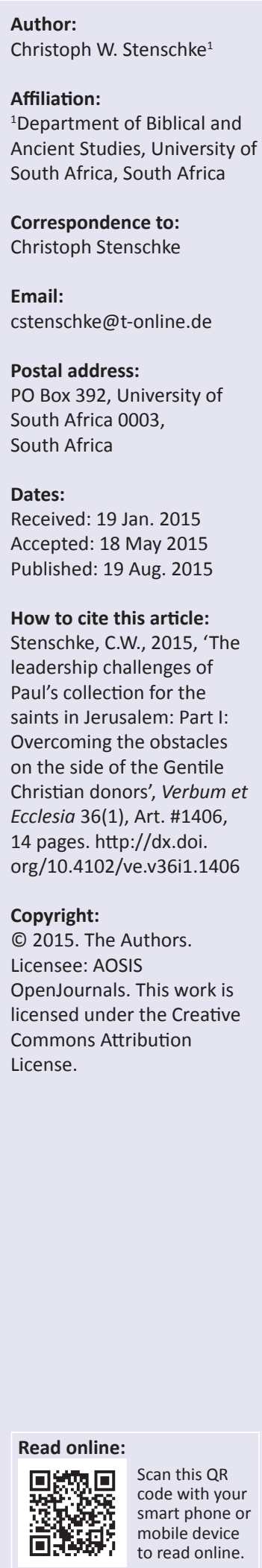

Author:

Christoph W. Stenschke

Affiliation:

Ancient Studies, University of

Correspondence to:

Christoph Stenschke

Email:

Postal address:

South Africa 0003

Dates:

Accepted: 18 May 2015

Paul's collection

saints in Jerusalem: Part I:

obstacles

Christian donors', Verbum et

Ecclesia 36(1), Art. \#1406

14 pages. http://dx.doi.

Copyright:

licensed under the Creative

Commons Attribution

to read online.
In addition to many other activities, the Apostle Paul was involved in a large-scale fund raising project. Following a charge he once had received in Jerusalem to remember the poor (G1 2:10), Paul tried to convince the predominantly Gentile Christian churches which he had founded to contribute to a collection for the impoverished Jewish Christians of Jerusalem. For the potential donors it was far from obvious that they should be involved in benefaction for people far away and unable to reciprocate to their would-be 'patrons', to name but one obstacle. Whilst Paul is best known as theologian, missionary and pastor, his collection project also indicates his determination and skills as an early Christian leader. In this quest, Paul combined a broad salvation historical perspective, skilful persuasion and rhetoric, the notions of honour and shame, exemplary transparency and other aspects. This article describes what obstacles Paul had to overcome on the side of the Gentile Christian donors, how he did so and how he proceeded in preparing and organising the actual collection, the transport of the funds to Jerusalem and its presentation in Jerusalem. In closing, the article suggests applications for today's Christian leaders.

Intradisciplinary and/or interdisciplinary implications: The article indicates that already in early Christianity Christian leadership involved the use of several skills and was controversial. Far from being able to simply demand a certain course of action, early Christian leaders such as Paul had to convince others to lead by their own example and had to be involved themselves in what they demanded of others. This challenges some contemporary notions of Christian leadership. Following the portrayal of Paul's leadership as it emerges from his collection project will lead to more effective Christian leadership.

\section{Introduction}

Before opening a new phase of his mission ministry in the west at the end of his third missionary journey, the Apostle Paul returned once more to Jerusalem with a delegation of Christians representing the predominantly Gentile Christian communities which he had founded in the Eastern Mediterranean world (Ac 20:4f.). They brought a substantial sum of money with them for the poor Christians in Jerusalem. For Paul, the funds were to meet the material needs, but far more was at stake: the collection was intended as an expression of Gentile Christian recognition of debt to Israel/Jewish Christianity and as an effort of reconciliation and mutual recognition between some Jewish and Gentile Christians. Paul's collection made high demands on all Christians involved: for the Gentile Christians, Jerusalem was far away; therefore no bestowal of local honour was to be expected in return for contributing to the collection. In addition, in the context of well-attested Gentile anti-Judaism, the Jews were a suspected minority in the Roman Empire. Bestowing benefactions on them was not a natural choice. For the Jewish Christians of Jerusalem to accept the donation - and with the sum of money, its donors! - implied the recognition of these Gentiles as part of the people of God and a relegation of their own ancient Jewish privileges. The delivery of the collection and its acceptance, perhaps impressively staged by Paul, would happen in Jerusalem and would not remain a private, inner Christian matter. Jewish Christians who would relativise their Jewish privileges in this way would face resistance and criticism from fellow Jews in a politically increasingly tense climate in the decade leading up to the first Jewish war (66-73 AD). Paul himself invested time and effort, had to delay his own plans, travel eastward once more and face a number of risks. Against this backdrop, the actual gathering of the funds, the transport to Jerusalem and the delivery posed severe obstacles and required all of Paul's leadership skills to overcome them.

Whilst we do not know precisely what happened in Jerusalem in the early summer of 56 or 57 $A D$, when Paul eventually arrived in the city to deliver the funds which he had collected (for 
the dates, see Riesner 2011; according to Murphy-O'Connor 1996:316, Paul planned to go to Corinth 'during the summer of $\mathrm{AD} 55$, in order to finalise the collection, on which he had been working for four years'), Paul's collection offers fascinating insights on Paul the Leader in a long-term, large and apparently disputed project which involved many and diverse people in critical circumstances. Paul's collection constitutes a case study for Christian leadership under difficult circumstances.

We shall first briefly survey the origin and development of Paul's collection for the saints of Jerusalem (section II; for a recent survey, see Downs 2008; for issues of poverty in the Greco-Roman world and in the Pauline literature see Longenecker 2010). Then we examine what was involved on the side of the Gentile Christian donors (focusing on Corinth, section III). What were the obstacles that had to be overcome in getting involved? How did Paul address these obstacles and try to overcome them in 1 Corinthians 16 and 2 Corinthians 8-9 (section IV)? After an exegetical survey we summarise at the end of this section how Paul addressed each of these obstacles and advanced this project which involved so many pitfalls. In the final section (V) we draw out the implications for Christian leadership today.

The second part of this study (The leadership challenges of Paul's collection for the saints in Jerusalem: Part II: Overcoming the obstacles on the side of the Jewish Christian recipients and on the side of Paul) will first examine the obstacles on the side of the Jewish Christians in Jerusalem. How did or would Paul address them? We also ask what obstacles Paul himself had to overcome in his collection project. A final section analyses and describes the overall portrait of Paul as a leader that emerges from the collection.

\section{The origin and development of Paul's collection}

The origin of Paul's collection enterprise is not fully clear. Two passages are of interest for this question and both raise a number of issues.

If Galatians is to be dated early (presupposing the so-called South-Galatian theory, i.e. the recipients are in the Roman province of Galatia; for the full argument see Carson \& Moo 2005:458-468), then Galatians 2:10 constitutes chronologically the first reference to a collection in which Paul was involved. On Paul's second visit to Jerusalem as a Christian (according to his own account in Galatians 1f.), he met with leaders of the Jerusalem Christian congregation (2:2) and reached an agreement with them (2:9). Whilst fully accepting Paul and his ministry among the Gentiles, they placed one obligation on Paul, namely 'that we remember the poor, which was actually what I was eager to do' (2:10). The note has a private character: it was a personal charge to Paul, not to all the Gentiles whom had and was about to convert. Probably at a later stage during his so-called second and third missionary journey (for an excellent survey of Paul's mission, see
Schnabel 2008:39-122), Paul extended this charge to all the Christians within his sphere of ministry. ${ }^{1}$

Many have noted the strange absence of the collection in the book of Acts (for a survey, see Downs 2006). There may be a cryptic reference to the collection in Acts 24:17 where it might appear in the disguise of private piety: 'I came to bring alms to my nation and to offer sacrifices'. Acts 20:4f. mentions the delegates from various areas of Paul's ministry who met with him at the end of the Lukan third missionary journey in order to travel with him to Jerusalem. Although this is the beginning of the third 'we-passage' in Acts (see Carson \& Moo 2005:290f.) no reason is given for the sudden accompaniment of these delegates to Jerusalem. In the context of Paul's arrival and meeting with the Christian leaders of the city, no mention is made of a collection (21:17-25; Paul is asked to pay for some rites in order to demonstrate his own Jewish identity and loyalty to his fellow Jewish Christians he probably used money from the collection fund). ${ }^{2}$

However, it is noteworthy that Acts tells of an early visit of Paul to Jerusalem (according to Acts, his second visit to the city after his conversion/calling). At that point Barnabas and Paul were sent by the Christians of Antioch to Jerusalem with donations to relieve a famine (11:27-30; see Riesner 1998:125-136). There are good reasons to equate this visit to Jerusalem with the visit reported in Galatians 2:1-10 (see Carson \& Moo 2005:319f.; Wenham 1993), one of them being that both events at least include gifts to the poor. Probably on this occasion, when Paul met with the Jerusalem leaders (as reported in Galatians 2) they charged him to continue to remember the poor which, writes Paul, 'was actually what I was eager to do' (Gal 2:10).

Paul's collection for the saints in Jerusalem, as it is generally understood, comes into focus during the second missionary journey. In 1 Corinthians 16:1-4 Paul addresses the collection as something that needed no further introduction, as the Corinthians must have been aware of it (for details, see Stenschke 2011). The Corinthians are to follow the instructions which Paul also gave to the churches of Galatia (16:1; we shall return to these statements when we examine Paul's response to the obstacles in Corinth). In 2 Corinthians $8 \mathrm{f}$ Paul goes to great lengths to persuade the Corinthians to overcome these obstacles. The last reference to the collection appears in Romans 15:22-31, where Paul informs the Roman Christians of his impending journey to Jerusalem to deliver the collection. He voices concerns regarding his own safety and regarding the acceptance of the collection by the

\footnotetext{
1.Even if Galatians is to be dated late (for the arguments, see Carson \& Moo 2005:460f.), Paul is not referring to the present time of writing (in this case round about $55 \mathrm{AD}$ ), but to events some 17 years after his calling ( 3 years and 4 years, 1:18 and 2:1; for discussion, see Riesner 1998). So even with the late date of the letter, this would still be an indication concerning the origin of the collection.

2.Possibly the fact that Paul came to Jerusalem with a group of Gentile Christians who represented various areas in the north-eastern Mediterranean world in which Pau represen found had founded churches, was a further reason for the request made by the Jerusalem leaders of paulto demonstrate his own Jewish identity. The reason Luke provides fo this demonstration is the false accusations concening Paul's ministry in the Jewish Diaspora that had spread in Jerusalem and were believed by many Christians in the city.
} 
Christians of Jerusalem and requests the Romans' prayer support. $^{3}$

\section{Obstacles on the side of the Gentile Christian donors}

From the references to the collection in 1 and 2 Corinthians it is clear that the eager participation from the Gentile Christians - which Paul perhaps had expected and certainly demanded - was far from obvious. Paul had to use all his leadership and rhetorical skills to persuade some of his Gentile Christian converts to participate in his collection project. In this quest we have to rely on Paul's own statements and own estimate of the situation, as other sources are not available. This involves some 'mirror-reading', a method that has been severely criticised and defended in recent research (for the methodological issues involved in this exercise, see Barclay 1987; Gupta 2012 and Hardin 2014). It is not clear what to make of the silence of other New Testament authors regarding Paul's collection for the saints of Jerusalem (most notably the silence of Acts) or of Paul's own silence in his later letters. Was the collection a matter of the past that had accomplished its purpose and needed no further mention, or did Paul perhaps have good reasons not to mention the matter again, as it did not achieve its intended purpose and perhaps ended in disaster?

There were two obstacles which concerned all Gentile Christian donors in the north-eastern area of the Mediterranean world of whom we know (Galatia, Macedonia, Achaia).

\section{Ancient local patronage and local honour}

There are several instances of upper-class people in the ancient world serving as donors and recipients of public honour (through statues and inscriptions) in other places. For example, King Herod the Great did not only rebuild and enlarge the temple in Jerusalem and fund other projects within his realm, but also outside of it (for a survey, see Schürer, Vermes \& Millar 1973:304f., 308). But within the prevalent ancient reciprocal system of patronage, the usual praxis of benevolence was to use funds locally to enhance one's own status within the community and to thus gain public recognition and honour and increase one's own status within the community. ${ }^{4}$ Garland (2003:752) reminds us that in Greco-Roman society generally, charity towards strangers was not considered as a virtuous act or as something to be divinely rewarded. When people gave to others they saw it as an opportunity to display personal virtue and social power, not their compassion. Due to these conventions, people gave primarily or only to those who were capable of giving them something in return. This could be repayment in kind or the bestowal of honour by lauding the donors publicly. This practise was based on the

\footnotetext{
3.For a survey, see Jewett (2007:918-940). A number of suggestions have been made as to the conceptual background of Paul's collection (did Paul follow any known as to the concep model for the collection of funds from Diaspora Jews or Gentiles for Jerusalem? here. For recent surveys, see Kim (2002), Downs (2008) and $\operatorname{Kim}(2011: 18-23)$
}

4.For surveys, see Lampe (2003), Marshall (2009:24-173) and Nojima (2011:143-246). assumption that it is most blessed to receive honour from others. This prospect motivated giving. In contrast to these notions, Paul expects the Corinthians to give generously for people they have never met so as to bring praise to God and not to themselves.

In this context and from this perspective, it made little sense to donate to recipients hundreds of miles away who were not able to reciprocate in any meaningful way: no or very little local status enhancing public acknowledgement or honour was to be expected for the donors for this type of benefaction. Those contributing to Paul's collection renounced (some of) their chances to gain status at home. Ascough (1997) has rightly observed:

For the Christian groups themselves their first priority seems to have remained their local congregations. ... Paul's troubles with raising the money promised, and his rhetorical strategies in his letters to the Corinthians ... suggest that they, at least, remained unconvinced that they had a social and religious obligation to an otherwise unknown group. What confuses the Corinthians is not necessarily the fact that they have to donate, but that the monies are going to Jerusalem rather than the common fund of the local congregation. (p. 237)

In addition, as Paul expected all Christians to be involved, there was little potential for status-enhancement within the wider Christian community through generous contributions to the collection (if that was of any concern to the Corinthians).

\section{Ancient anti-Judaism}

Whilst many Gentiles were attracted to Judaism in varying degrees (from full proselytes to sympathising 'God-fearers') there was also the latent and at times violent anti-Judaism of the Roman world (for surveys, see Bohak 2010; Feldman 1993; Schäfer 1997). The account in Acts 18:12-17, located in Corinth, shows clear traces of this (see Stenschke 1999:78f.). For Gentile Christians without prior attachment to Diaspora Judaism (it is difficult to estimate what percentage of Gentile Christians in Pauline communities were in that category) it was far from obvious to donate to impoverished Jews in Jerusalem.

Such hesitations on the side of some (influential) Corinthians were all the more likely the case, as some ancient Roman authors accused the Jews, due to their strict Sabbath observance (Juvenal, Sat. 15,105f.; Tacitus, Hist. 5.4; see Goldenberg 1979) of being a particularly lazy people. ${ }^{5}$ So, if some Jewish people in Jerusalem were in need, perhaps a popular response by those who were informed about it, the solution was obvious: let them work more! However, it is difficult to ascertain to what extent such prejudices - clearly attested for Rome - were prevalent in Corinth.

Three other obstacles were peculiar to Corinth/Achaia. 


\section{Paul's quarrels with the Corinthians and the presence of opponents}

Both letters to the Corinthians indicate strained relationships between Paul and some of the Corinthian Christians. Whilst 1 Corinthians is more didactic than apologetic (here I follow Hafemann 1993:174 against Fee 1987:4-19), by the time Paul wrote 2 Corinthians, in addition to all the various quarrels between Paul and the Corinthians regarding doctrine and ethics (to which both extant letters amply testify), there were a number of fierce opponents in Corinth. According to Hafemann, by the time Paul wrote 2 Corinthians the situation had completely changed. Apparently between the writing of 1 and 2 Corinthians, the whole church opposed Paul and his gospel under the influence of Paul's opponents who had recently come to Corinth (cf. 2 Cor 11:4). However, since then a larger group in the church was back on Paul's side. But his apostolic authority is no longer accepted by the entire church. There remains a substantial opposition to Paul among the Corinthians, with his opponents lurking behind them. As a consequence of this development, the church now was divided over Paul and the legitimacy of his apostolate. ${ }^{6} . .$. Whilst the problems in 1 Corinthians were within the church, the crucial issue to be resolved in 2 Corinthians is Paul's authority and legitimacy as an apostle. ${ }^{7}$ Regarding the strategy of these opponents, Hafemann suggests that Paul's opponents had capitalised on the Corinthians' over-realised eschatology. They promoted a view of Christ and of the Spirit that appealed to the Corinthians (2 Cor 11:4). Instead of admonishing them:

to endure faithfully in the midst of adversity in hope of their future resurrection and vindication, Paul's opponents promised the Corinthians a life in the Spirit that was characterised by deliverance from suffering and by a steady diet of miraculous experience. (Hafemann 1993:175)

Their claims to be apostles were based on letters of recommendation from other churches (cf. 2 Cor 3:1), on their ethnic identity as Jews (2 Cor 3:4-18; 11:21f.) and on their boasting attainments and supernatural signs, together with apparently impressive rhetorical abilities (2 Cor 10:10, 12; $11: 12,18 ; 12: 12){ }^{8}$

If this reconstruction of their teaching is correct, some Corinthians or the opponents there might have suggested a simple and obvious solution to the needs of the Christians of Jerusalem based on such over-realised eschatology: let these Christians simply live in the Spirit and experience divine deliverance from their suffering, including their material

6.According to Hafemann (1993:174): "This current condition is reflected in the absence of the call to imitate Paul in 2 Cor, in the consistent focus on Paul's own authority as an apostle throughout most of 2 Cor, and lost clearly in the differen ways in which Paul's suffering functions in the two letters. In 1 Cor 8-13 and 9:1-27 Paul's suffering can be used to support his argument on behalf of the Corinthians, whereas throughout 2 Cor Paul must argue for the legitimacy of his suffering itself (cf. 2 Cor 2:17; 1:7-15: 12:13-18)'.

7. Hafemann (1993:174) goes on to describe the origin of the problems in Hellenistic culture and an overistic more more boasting and disunity in the congregation. It also led to the eventual rejection of Paul's legitimacy as an apostle and of his gospel (p. 175). For Paul's opponents in Corinth, see also Summney 1990 and the essays in Porter 2005.

8. Hafemann (1993:175) also describes how Paul addresses these issues, pp. $177 f$. needs. All of this should be all the more so the case, as they can also claim ethnic distinction as Jews! And let the money stay in Corinth! Whatever is donated for Jerusalem would no longer be available for Paul's opponents who apparently readily accepted gifts from the Corinthians.

One further aspect needs mention. Murphy-O'Connor (1996:319) notes, regarding the Judaising opponents of Paul who may have claimed links to Jerusalem, that the significance which Paul attached to the collection gave them the opportunity to highlight Paul's suspiciously ambiguous attitude towards money. Whilst he refused money for himself, he solicited it for the poor. Would all the money really end up in Jerusalem? When questioned by the Corinthians about the needs of the Jerusalem church, all that Paul's Judaising opponents had to do was simply to shrug their shoulders. They did not even have to question the need for the collection. They simply had to insinuate that the Corinthians were a little naive in taking Paul's claims regarding the need at face value. By emphasising the fact that Paul had taken money from the Philippians (2 Cor 11:9), they could argue that Paul did not appreciate the Corinthians whose generosity he had refused. This brings us to the next point.

\section{Paul's financial policy in Corinth}

Another obstacle was peculiar to Corinth. Whilst ministering there Paul had refused to accept money from the Corinthians (although he defends his principal right to do so in 1 Cor 9:1-14) and insisted on meeting his needs through his own manual labour. ${ }^{9}$ Paul refused to depend on the local upperclass Christian patrons whose client he would have become by accepting their support. ${ }^{10}$ Furnish (1984:507f.) spells out the implications of this decision:

In the ancient world, giving and receiving, placing someone under and being oneself placed under financial obligation were extremely important components of the social structure. Thus, within Roman society specifically - and the Corinth Paul knew was a Roman colony - the wealthy expressed and enhanced their power by becoming patrons of the needy. The extent of one's philanthropies and the number of one's clients were important measures of a person's social standing and influence. (p. 507f.)

The recipients of such benefactions were immediately placed under an obligation of gratitude to their benefactors. This gratitude of the beneficiaries in turn placed the benefactors under further obligation and so on. Therefore, the acceptance of a gift meant to become the client of and dependent upon the more privileged person (the benefactor), even though the patron was also placed under the obligation to provide further benefaction. This kind of relationship was motivated not by friendship (although some conventions of friendship were there), but by the patron's desire for power and prestige

9.For several reasons, this would have been an embarrassment to the Corinthians; see Furnish (1984:507).

10.According to Schnabel (2004:1450), the acceptance of patronage would have signified a compromise of the gospel. Paul perhaps would have lost the freedom to preach the gospel to all people with all the consequences that the message of the crucified and risen Jesus Christ entailed for the personal behaviour of the wealthy citizens as well. 
and from the client's need of assistance. Often friends were made by money. In this context where friendship was based on benefaction and not the other way round, the refusal of benefactions was considered an act of social enmity. For all these notions an elaborate protocol had been developed in Paul's day. Against this social backdrop, it is understandable why the Corinthians were annoyed by Paul's refusal to accept their benefactions: in doing so, Paul renounced their status as a 'patron congregation' (cf. 2 Cor 12:13) and in their eyes repudiated their friendship (cf. 11:11). Paul's refusal (and the consequences it implied for him) would also have been seen as a regrettable act of self-humiliation.

In addition to unavoidable dependency, such relationships would have impeded Paul's further mission. Schnabel (2004:1451) observes that Paul refused the support of a church or individuals when his acceptance could disturb or destroy his missionary work in that particular church or the gospel that he proclaims due to the agitation of opponents. Some Corinthians apparently insisted that Paul should have accepted their support (1 Cor 9:1-18; 2 Cor 2:17). Perhaps the same people also insisted that Paul should have increased his success by employing more brilliant rhetorical means (see 1 Cor 1:17-2:5). These are perhaps the same believers who wished to influence his travel plans (2 Cor 1:17). With regard to this kind of thinking and demand, Paul insisted that the content and the success of his missionary preaching, as well as the practical side of his missionary endeavours are dependent upon God alone, both with regard to rhetorical techniques or the lack thereof (and other methods, such as the use of signs and wonders; see Rom 15:19) and with regard to his travel plans and his financial independence.

This issue led to tensions with some Corinthians. Paul's opponents would have readily attacked his policy. ${ }^{11}$ At the same time, Paul readily accepted gifts from other churches (Phlp 4:10-20) and even tells the Corinthians about it in 2 Corinthians 11:8-9:

I robbed other churches by accepting support from them in order to serve you. And when I was with you and was in need, I did not burden anyone, for my needs were supplied by the friends who came from Macedonia. So I refrained and will continue to refrain from burdening you in any way.

Furnish (1984:507) observes that the Corinthians were probably distressed with Paul's refusal of support from them because it appeared to be inconsistent with his accepting support from other congregations. Whilst in Thessalonica Paul had received contributions from the Philippians at least twice (Phlp 4:16), in addition to what he was able to earn from his craft (see 1 Th 2:9). The Philippians continued supporting Paul even after he left Macedonia (Phlp 4:15). It is likely that the support which Paul received whilst in Corinth was provided by certain brothers who came from Macedonia (2 Cor 11:9), having been sent by the Philippians. For his critics, this would be further evidence of

11.Murphy-O'Connor (1996:319); see also Martin (1986); Marshall (1987) and Chow (1992). the inconstancy and inconsistency of which they had long suspected and accused him.

Whilst refusing their support (with all the strings attached to it), Paul at the same time expected the Corinthians to contribute to the collection and to provide the means for his own travelling and for his co-workers as he writes in 1 Corinthians 16: 'so that you may send me on my way, wherever I go' (v. 6); 'send him on his way in peace, so that he may come to me' (v. 11); 'I urge you to put yourselves at the service of such people, and of everyone who works and toils with them' (v. 16).

It might have seemed to some that - in addition to all the other quarrels between Paul and them to which both extant letters of Paul to the Corinthians amply testify (see Fee 1987:4-19; Hafemann 1993), and despite his early insistence of his independence and refusal of patronage - now Paul was trying to get at their money after all. Could he be trusted? Would the money really go to Jerusalem? On the question of Paul's refusal of support in Corinth and his demand to participate in the collection, Furnish aptly observes:

His promotion of this project at the same time that he was declining to let the congregation become his own patron evidently aroused the suspicion, or allowed his rivals to plant the suspicion, that the collection was but a subterfuge, a way of gaining the support from the Corinthians without obliging himself to them as their client (see 12:16). This, too, seems to be behind Paul's remarks in 11:5-15. (Furnish 1984:508)

Some of this happened when Paul's opponents readily accepted payments from the Corinthians and for these reasons would have opposed the idea of sending money to Jerusalem. Hafemann (1993:175) notes that Paul's opponents affirmed their claims by demanding money from the Corinthians. This was to be a sign of the value and legitimacy of their message (2 Cor 2:17). But in order to make these claims and demand this payment, they attacked Paul himself and his apostolic legitimacy. Their attack called both their gospel and their lifestyle into question.

\section{Previous other financial engagement of the Corinthians}

Perhaps in apparent conflict with our first observation regarding reluctance in translocal involvement, a further reference needs brief attention. The last words of 2

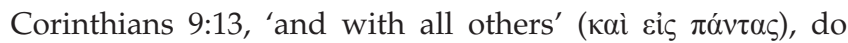
not mean that 'the saints' will also glorify God over the involvement of other churches (which Paul will have hoped for). Rather, they suggest that the Corinthians also share or had also shared with (all) other Christians: '... the generosity of those who graciously share their resources with them [the Christians of Jerusalem] and (so the saints may presume) with all Christian brothers and sisters'. ${ }^{12}$ Although some of this sharing could and most likely will have happened among the Corinthians (or the Christians of Achaia), it was

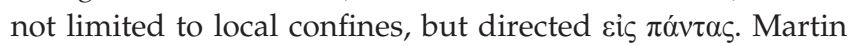
12. Furnish (1984:451), for the limitation to Christians, see p. 445 . 
(1986:294; italics mine) comments: 'This should strictly mean that the Gentile congregations raised money and gifts for other churches and worthy causes other than the needs of the people at Jerusalem'. However, as we have no knowledge of such actions, Martin (1986:294) suggests that the phrase must be taken 'to be a general one in praise of the generous spirit that moves the readers, and would move them wherever there may be need'. Yet, the fact that we might not know of such actions does not mean that Paul simply praised a generous attitude. Therefore the statement should be taken at face value. ${ }^{13}$ If 'all others' refers primarily to Christians in Achaia (2 Cor is addressed to the Corinthians, 'together with all the saints in the whole of Achaia', 1:1), there would have been some benefits for the Corinthian donors - at least more benefits than from donating for Jerusalem. Such giving of the Corinthians would have secured them a prominent role among the Christians in Achaia. This explains the intensity of Paul's interaction with the Corinthians and his opponents there. Possibly the scope was wider than Achaia. We do not know what role Paul may have played in this past sharing of the Corinthians. ${ }^{14}$ This past and present sharing with 'all others' may also account for the Corinthians' reluctance to get involved in yet another translocal project, particularly as it was a project that was - to some extent - beyond their control.

\section{Paul's responses to these obstacles}

It is instructive to read Paul's letters to the Corinthians against this backdrop. How did Paul the Leader seek to overcome this barrage of obstacles? This is not the place to analyse Paul's full argument in both letters in detail; rather, we note how Paul addresses these obstacles primarily in the context of the collection enterprise. We cannot examine how Paul deals with inter-church solidarity, anti-Judaism, his opponents, how he defends both his own apostolic calling and status, and explains and defends his financial policy throughout both letters.

In 1 Corinthians 16:1-4, Paul instructs the readers to follow the instructions given to the churches of Galatia, which apparently were known in Corinth (for detailed discussion of the passage, see Garland 2003:750-757). ${ }^{15}$ The collection is by no means a project designed particularly to get at the Corinthians' money, but part of a larger project where the same demands and rules apply to all. The same instructions apply to all churches; the Corinthians are but 'one pebble on the beach'. Paul indicates that the Galatians were also called to contribute to a translocal project. Whilst not obvious for some Corinthians, translocal responsibility for other believers is part and parcel of Christian identity.

13.It is unlikely that Paul, by using $\pi$ óv $\tau \alpha$ c refers to the other churches involved in the collection. In that case the Corinthians might have contributed to a 'common fund'.

14.Possibly Paul refers to funds that he expected churches to contribute to his mission cf. Dickson (2003:178-213) ('Providing for the Gospel: Mission-commitment as financial assistance').

15.Garland (2003:751) argues that with 1 Cor 16:1-4 Paul is responding to another issue raised by the Corinthians in their letter to him. He had previously asked the Corinthians to participate. Now they inquire about the best way to make this collection. 'Since he gives instructions only for the actual collecting of the money, they appear to have asked him how they should manage its implementation'.
Paul also instructs that all Corinthians are to be involved ('each of you', v. 2). Christian charity is not just a statusenhancing project for the wealthy upper-class members and of no concern to other Christians. Garland (2003:754) notes that throughout the letter Paul seeks to build up horizontal relationships among the Corinthians. His expectation that everyone will take part in this project on a voluntary basis furthers this goal. If only a few patrons were to provide all the money, they would gain all the honour for themselves. This would divide the rich from the poor even more. If free artisans, small traders and slaves also give whatever they can contribute, then the gift will represent the entire church; not just a few wealthy donors. ${ }^{16}$

In addition, the collection of the funds should be wellstructured and organised: 'on the first day of every week, each of you is to put aside and save whatever extra you earn ...' Garland (2003:753) identifies several principles that undergird Paul's instructions for the collection. The money is to be collected regularly ('on the first day of every week'), by all in the congregation ('let each of you'), systematically ('set aside', 'save up'), in proportion to income ('as one has been prospered') and without pressure from outside ('so that no collections might take place when I come'). ${ }^{17}$

The Corinthians themselves are to approve the delegates who take the gift to Jerusalem, together with a letter explaining the collection and its purpose: 'And when I arrive, I will send any whom you approve with letters to take your gift to Jerusalem' (v. 3). ${ }^{18}$ Against possible suspicions regarding Paul's use of funds entrusted to him, Paul guarantees full transparency in the matter: the money will not go through and eventually end in his own pocket. ${ }^{19}$ Rather, delegates from Corinth and approved of by the congregation will deliver the funds directly to Jerusalem. They will see to the delivery and will have an opportunity to see the need in Jerusalem themselves. Now they have to take Paul's word for it, then they can see for themselves. Paul's contribution will be an explanatory letter to Jerusalem. However, if it seems advisable that he should travel also, these delegates will accompany Paul (v. 4; Paul does not indicate why it might become advisable for him to

16.This charge for all to be involved agrees with Paul's emphasis on the unity of the church throughout the letter. Hafemann (1993:178) observed: 'It is striking that most of the commands throughout 1 Corinthians centre on some aspect of church unity (cf. 1 Cor $1: 10 ; 3: 1-3 ; 4: 14,16 ; 5: 4,5,7,8 ; 6: 1,4,6 f ., 18,20 ; 8: 9,13 ; 10: 14$; 11:33f.; 12:14, etc.). Clearly Paul's primary concern is with the true nature and life of the church, making ecclesiology the most important theme of 1 Corinthians. As of the church, making ecclesiology the most important theme of 1 Corinthians. As the "church of God" (1 Cor 1:1), the Corinthians are "the temple of God", due to their reception of the Holy Spirit (1 Cor 3:16f.; 14:24f.); and the "body of Christ", due to their submission to the lordship of Christ (1 Cor 6:17; 10:17; 11:29; 12 :
$12-16,27)^{\prime}$.

17.Regarding this stipulation, Garland (2003:754f.) observes that by taking up the collection in advance to Paul's coming, the Corinthians are completely free in how much they contribute, and he will not know who contributed what. Possibly, he wanted to avoid being perceived as twisting arms to get money by asking in person (cf. 2 Cor 9:5) or did not want to take time from other labour to try to raise money.

18.Garland (2003:755) observes that, whilst the collection is Paul's special project, he does not infringe on the church's autonomy in choosing their representatives. Each individual decides how much to give. The church decides whom they will entrust to represent them in this enterprise.

19.According to Garland (2003:755), Paul may also have been sensitive to possible accusations of chicanery (cf. 2 Cor $8: 20 ; 12: 14-18$ ). A recent event made a collection for Jerusalem a critical endeavour. According to Josephus (Ant. 18.3.5 $\$ 81)$, a Palestinian Jew and three cohorts induced one of their notable Roman converts, Fulvia, to send treasures to the temple in Jerusalem. However, rather converts, Fulvia, to send treasures to the temple in Jerusalem. However, rather
than delivering the goods to Jerusalem, they disappeared with them. When their fraud was discovered Tiberius ordered all Jews to be banished from Rome. 
come along). Paul is not only making demands of others: he is willing to bear his share of the burden. For him this would mean the delay of his own plans, a strenuous and costly journey eastward when his mind was already set elsewhere, and high personal risk due to fierce Jewish opposition to his ministry (see Rm 1:13-15; 15:19-31). Acts 20:4ff. indicates that this option is what materialised later on.

In 2 Corinthians 8-9, Paul first reports of the exemplary involvement of the Christians of Macedonia (again, the collection is not specifically aimed at the Corinthians' wealth, but an 'ecumenical' project!). The Macedonians already display an exceptional inter-church solidarity. The Corinthians should do likewise. In the Corinthians' hearing, Paul exuberantly praises the Macedonians for their generous participation despite their poverty: 'for during a severe ordeal of affliction, their abundance of joy and their extreme poverty have overflowed in a wealth of generosity on their part' (2 Cor 8:2). Furnish (1984:431) notes that Paul's comment about the extreme poverty of the churches in Macedonia suggests that he perceives the Corinthian Christians to be relatively well-off. ${ }^{20}$ In this way Paul adds pressure to his charge. The wealthier Corinthians are not to be put to shame by the generosity of the poor Macedonian Christians! Paul's praise of the Macedonians was to challenge the Corinthians and spur them on to contribute with similar commitment. ${ }^{21}$ Whilst for the Corinthians, local honour for such involvement was limited or non-existent, the Corinthians will likewise receive this kind of public honouring from Paul before the wider Christian community if they also contribute generously. What they forgo in local honour by participating, Paul will also lavish on them before the wider Christian community - the body that really matters.

Paul calls the Corinthians to excel in this matter as they have excelled in others. He creates a sense of rivalry between the Christians of Macedonia and Corinth. In the ancient value system of honour and shame - in particular when honour was a considered a desirable but limited good - this was a powerful strategy..$^{22}$ The earnestness of others (i.e. the Macedonians), which Paul reports in some detail, serves to challenge and to prove the genuineness of the Corinthians' love (v. 8). ${ }^{23}$ They were to complete now what they had begun in the past (vs. 10-13).

Other Christians (the Macedonians) fully accept Paul's apostolic authority and wholeheartedly joined this project

20.For the reasons of this poverty in Macedonia, see Furnish (1984:413). Were the Thessalonians less poor than other Macedonian Christians in general and therefore able to help them financially? Was it through this display of love that their example in suffering (1 Th 1:6-8) became widely known in Macedonia and Achaia?

21.Paul's sending of Titus and others to complete the collection among the Corinthians suggests that Paul did not rely only on his previous charge to the Corinthians and the good example of other Christians (2 Cor 8:6). Somebody trusted by Paul (and the Corinthians!) was to attend to the matter 'on site'.

22.On ancient notions of honour and shame, see Janssen and Kessler (2009); Matthews (1996) and Plevnik (2000).

23.The giving of the Macedonian Christians is mentioned again in 2 Cor 11:9: Paul accepted from the Macedonians what he refused from the Corinthians (some Corinthians should be ashamed of themselves!); on the relation of Paul's refusal of support in Corinth and his urgent call to participate in the collection, see Furnish (1984:508). despite the sacrifice it involved for them. Paul's opponents and their sympathisers in Corinth should take note of this!

Then Paul refers to the Jewish Messiah, the Lord Jesus Christ, who, though he was rich, for their sakes he became poor, so that by his poverty they might become rich (8:9). The Corinthians have already benefitted tremendously from the Jewish saviour and the salvation intended primarily for Israel. So to support some Jews 'in return' is not as odd as might have seemed to some Corinthians!

Christ's example challenges all notions of reciprocity and status gain. In 2 Corinthians 8:12f., Paul describes Christian sharing and his vision of fair balance: the Christians in Jerusalem in their need should benefit from the Corinthians' present abundance. At some point in the future it may be the other way round ('so that their abundance may be for your need'). This principle is motivated by a quotation from the Exodus story of God's provision for Israel. This is the grand narrative to which the Corinthians are or should be indebted. The need of the Christians of Jerusalem is a temporary matter and not caused by any inherent character weakness or otherwise.

Paul then mentions several other people who are also involved in the collection. It is far from being a private project of Paul's directed at the Corinthians' money! Again Paul emphasises transparency (vs. 16-24). Paul's co-worker Titus shares the same eagerness for the Corinthians (as Paul, an assurance of his affection for them) and is on his way to Corinth of his own accord (v. 16f.). Titus fully identifies with this project and is convinced of the Corinthians' readiness and generosity. He will be accompanied by an unnamed Christian, sent by Paul, who is famous among all the churches for his proclamation of the good news (for discussion of his identity, see Walker 2011). The Corinthians had better not disappoint a man thus qualified! In addition, this brother:

has also been appointed by the churches to travel with us whilst we are administering this generous undertaking for the glory of the Lord himself and to show our goodwill. (v. 19)

Other churches fully participate in the collection enterprise and have already appointed this delegate to go with Paul to Jerusalem. Elsewhere Christians fully accept Paul's authority and join this project. Paul leaves no doubt that elsewhere, Christians - be they exemplary individuals of something as wide as 'all the churches' - have no suspicions regarding the apostle and his financial policies.

This prominent Christian (and the other two men) can also serve as independent witnesses to the Corinthians and the churches who sent him regarding the integrity of Paul and later on of the events during the journey and in Jerusalem. There is also an element of threat in Paul's references to 'all the churches' and 'the churches': how the Corinthians respond to Paul's request, and these brothers is not just between them, but happens before all the churches which hear of it - this is where the Corinthians will receive honour or shame for their response to Paul's demand. 
Far from being a project to enhance Paul's personal status, the collection's prime purpose is 'for the glory of the Lord himself' and 'to show our goodwill' (probably an inclusive plural: Paul and all the other participants, v. 19). Neither is this act of benefaction designed to bring recognition and honour to the donors (which would have been the purpose of ancient benefaction). Its purpose is for the glory of the Lord himself. Therefore generous participation is mandatory. The gratitude of the recipients will be directed primarily to God ('but also overflows with many thanksgivings to God', 2 Cor 9:12). That has to suffice for the donors. At the same time, God will provide every blessing in return (2 Cor 9:8-15).

Paul openly asserts his concern for his integrity and full transparency in the matter:

We intend that no one should blame us about this generous gift that we are administering, for we intend to do what is right not only in the Lord's sight [Paul's primary concern; the Lord cannot be fooled by people - neither by Paul nor by the Corinthians!], but also in the sight of others. (v. 20f.)

Thus the Corinthians should dismiss their reservations (and those of the opponents) concerning Paul and wholeheartedly participate.

In addition to Titus and the unnamed brother, Paul will send even another Christian to Corinth, whom he has often tested and found eager in many matters. This is a warm recommendation. Now this trustworthy and proven brother is more eager than ever (to come to Corinth and be involved there in the preparation of the collection) because of his great confidence in the Corinthians (v. 22). The eagerness (of both men) and the confidence which they have in the Corinthians, puts pressure on the Corinthians to not disappoint. Whilst Paul's own relationship with the Corinthians was strained for several reasons and his status disputed by his opponents in the congregation (amply indicated in both letters), this man is eager and fully confident in the Corinthians. ${ }^{24}$ Rather than coming himself at this particular moment, Paul sends men whose relationships with the Corinthians are not strained to accomplish his goals.

Regarding Paul's emissaries, Murphy-O'Connor (1996:315) notes that once before the Corinthians had given their assent to Paul's request and then nothing happened. This time Paul was not prepared to rely on their words alone. He decided to send these men, whose presence would be a continuous reminder of his request and their obligation. However, even this discreet pressure might be resented by the Corinthians as interference in their internal affairs. Paul's nervousness becomes apparent in his presentation of Titus. Paul emphasises that he is not really sending Titus, as 1 Corinthians 8:6 might imply. Titus returns to Corinth voluntarily in response to Paul's appeal (8:17).

24. Perhaps this is in contrast to Paul: writing two full chapters, 2 Cor $8 f$., to nudge the Corinthians on to participate and sending three men to see to the collection, may suggest that Paul himself was less confident that the Corinthians would do as he requested of them.
Paul closes with a warm recommendation of Titus: 'he is my partner and co-worker in your service' (v. 22). Paul is not trying to exploit the Corinthians for his purposes, but to minister to them through these men: 'in your service'. These other two men are 'messengers for the churches, the glory of Christ' (v. 23). Far more is behind their impending visit to Corinth than merely Paul: they come as messengers of the churches, the glory of Christ! In view of these visitors and witnesses and the wide ecumenical perspective which they constitute, Paul admonishes the Corinthians once more: 'Therefore openly before the churches, show them the proof of your love and of our reason for boasting about you' (v. 24). Generous participation in the collection is an opportunity for them to prove their love of the Lord and of their fellow Christians. They have already received honour through him (and more is in store for them!). Now they had better not let Paul down. The response of the Corinthians is a matter before all the churches: there they gain or lose honour. Again, there is concern beyond local confines (for the force of this argument, see Stenschke 2011). As Paul recommends these men, so he would also recommend the Corinthians in the future if they do as is expected of them.

In 2 Corinthians 9:1-5, Paul draws further on ancient notions of honour. He acknowledges the Corinthians' virtues: 'for I know your eagerness'. Paul has already boasted about this eagerness of the Corinthians to the Christians of Macedonia and thus enhanced their status within the wider Christian community, 'which is the subject of my boasting about you to the people of Macedonia, saying Achaia has been ready since last year' (v. 2). Murphy-O'Connor (1996:314) observes, regarding Paul's argumentation, that, even though he had 'to stretch the truth', he praises the willingness of the Corinthians (although it was now a year old; 9:2). Paul carefully avoids direct criticism. He explicitly writes that he is not ordering them to contribute (8:8a), but merely expressing his opinion (8:10). The Macedonians' exemplary response is introduced in such a way as to awaken the Corinthians' self-respect to become an internal incentive. In order to remove any concern on their part as to the sum expected, Paul emphasises that their attitude is more important than the actual sum (8:12). Yet near the end Paul highlights the possibility that he and the Corinthians might be humiliated by the much poorer Macedonians (9:4). Whilst Paul immediately wants to exclude any hint of moral blackmail by denying that he wants to extort money from them (9:5), there is still some pressure.

By mentioning the Macedonian Christians to the Corinthians, Paul indicates that he readily informs and praises the good that other Christians do and in this way bestows honour on them. Although participation in the collection will not serve to enhance local status, elsewhere this surely happens among the wider Christian community. Paul's earlier report of the Achaians' zeal (including the Corinthians) in contributing to the collection, has stirred up most of the Macedonians in their participation (at the beginning of chapter 8, Paul praised the Macedonians to the Corinthians in order to spur 
them on). This is the background to Paul's sending of the three brothers:

But I am sending the brothers in order that our boasting about you [to the Macedonians] may not prove to have been empty in this case, so that you may be ready, as I said [to the Macedonians and perhaps others] you would be; otherwise, if some Macedonians come with me [to Corinth, in addition to the three brothers?] and find that you are not ready [as Paul had said], we would be humiliated - to say nothing of you - in this undertaking [shame rather than honour for Paul and for the Corinthians]. So I thought it necessary to urge the brothers to go on ahead to you, and arrange in advance for this bountiful gift that you have promised [a reminder of their previous commitment], so that it may be ready as a voluntary gift and not as an extortion. (v. 3-5)

In 2 Corinthians 9:6-14, Paul outlines the spiritual benefits that are in store for the Corinthians: what the donors forfeit in local recognition and honour, they will receive abundantly from God: 'And God is able to provide you with every blessing in abundance, so that by always having enough of everything, you may share abundantly in every good work'. They have every reason to give cheerfully: the prospect of every divine blessing in abundance is far more than any human could reciprocate for benefactions received. For their generosity, they will be in every way enriched by God (v. 11).

There will be thanksgiving by the recipients, not addressed to the Corinthians, but to God (v. 12). By sharing in this ministry, they glorify God by their obedience to the confession of the Gospel of Christ, the Jewish Messiah, and they glorify God by their generosity in sharing with the Christians of Jerusalem and all other Christians (v. 13; the charge and practice of sharing applies not only to the Jewish Christians of Jerusalem, see above). In addition to all the spiritual benefits, the recipients will long for the Corinthians and pray for them (v. 14): 'Those who have been aided by the collection will also respond with intercessory prayers on behalf of their benefactors' (Furnish 1984:452). In view of early Jewish views of Gentiles, this longing of the Jewish Christians for Gentile Christians is all the more remarkable. Whilst Paul's Judaising opponents in Corinth make demands of the Corinthians, these Jewish Christians would intercede for them.

\section{Conclusion}

In closing, I summarise how Paul addresses the five obstacles which we identified above.

\section{Ancient local patronage and local honour}

1 Corinthians 16 and 2 Corinthians 8-9 deal directly or indirectly with the notions of benefaction, translocal responsibility and human and divine recognition of benefactions bestowed. Paul shows to the Corinthians that they are part of the larger entity of the Christian community and should act accordingly. The same instructions apply to all. Christians from Galatia and Macedonia are also involved. Against their own cultural notions, all Corinthians are to be involved as they may prosper. Paul's vision of Christian charity is counter-cultural: it is not aimed at enhancing the status of the wealthy. Paul is not only making demands of his converts, he is also ready himself to come along to Jerusalem. Paul exuberantly praises the exceptional involvement of the Macedonians who sacrificially practice inter-church solidarity. Whilst there will be no local honour in Macedonia, Corinth or Achaia, Paul generously praises Christian benefactors in the wider Christian community, which is the body that really matters. One day the Corinthians may benefit from the abundance and inter-church solidarity of other Christians. All the churches are behind the men whom Paul sends to Corinth to see to the collection. In addition, they will receive divine recognition and the recipients will long for them and pray for them. The whole project is designed to bring honour to God, not to people. Not people, but God will provide every blessing in return. His blessing surpasses everything humans could ever do to reciprocate. As Paul readily informs the Corinthians about the involvement of other Christians, so he will praise them or - there is probably some implicit threat - shame them. Therefore, participation in the collection is not merely a private matter.

Elsewhere in 1 and 2 Corinthians there are several references to translocal links and inter-church solidarity. Paul's many references to other Christians and their function have been analysed by Stenschke (2011). The Corinthians are 'not the only pebble on the beach'. These observations have recently been supplemented by James Thomas Hughes. In his study 'Ecclesial solidarity in the Pauline Corpus' (PhD thesis, University of Aberdeen, 2015), he argues a persuasive case for intra-church and inter-church solidarity (I adopt his terminology) in the Pauline Corpus. According to Hughes, there is evidence for concern for inter-church solidarity in

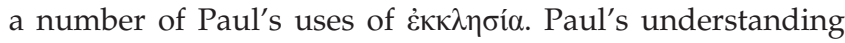
of inter-church solidarity in 1-2 Corinthians (of which Paul's collection is a concrete expression) becomes apparent in assertions of regional solidarity. Paul aims at creating solidarity among churches based on mutual recognition, imitation and support. This provincial or regional usage is a way of encouraging local churches to express solidarity with other believers as widely as possible, by learning from them, by imitating their behaviour and by supporting them (102). Paul also refers to normative behaviour: the implication of Paul's argumentation in 1 Corinthians 11:2-16 is that, what is normative in 'the churches' in general should also be normative in Corinth, as 'The Corinthian church must take account of what happens elsewhere' (103). There is an idea of common identity across all churches which expresses itself in common beliefs and practices. Paul also argues for mutual accountability (based on 2 Cor 8:18, 19, 23f; see above). His own relationship to the churches (Paul's concern for all the churches implies a model of concern which should be followed by the Corinthians) and the collective singular use

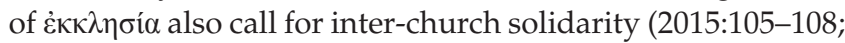
the Corinthians need to take account of the whole church when they act).

The same applies to Paul's use of other ecclesial imagery, namely the language of holiness, temple imagery, brothers, 
the body (109-124). Hughes argues that Paul's use of brother language in the letters shows Paul's continued awareness and concern for inter-church solidarity: 'the brotherhood of believers extends beyond the boundaries of Corinth, and the members of that wider brotherhood have responsibilities to one another' (120). As members of the whole body of Christ, the Corinthians are to take account of the whole church. Also Paul's references to his apostleship and imitation of him and other believers suggest intra-church and interchurch solidarity through norms and examples (125-135). Hughes concludes that by using the language of imitation and example as he does, Paul indicates that the Corinthians are part of a larger translocal body. What happens elsewhere should have an influence on them, whether as conduct to be emulated or avoided. Through the collection they also have the opportunity to influence what happens elsewhere in a positive way. All this makes explicit what is implicit in 1 Corinthians 1:2, 'together with all those who in every place call upon the name of our Lord Jesus Christ, both their Lord and ours', namely that they need to take account of what happens beyond Corinth (133).

\section{Ancient anti-Judaism}

With regard to the anti-Jewish 'obstacle' there are some references in the immediate context of the collection. The Jewish Lord Jesus Christ is the example. The Corinthians have already benefitted from this Jewish saviour who became poor for their sake and from God's salvation for Israel. The Jewish exodus account is the narrative to heed and that is to determine behaviour. There might come a time, when the Jewish Christians of Jerusalem will share their abundance with the Corinthians (and other Christians). Inter-church solidarity is not to be a one-way street.

In addition to these references in the context of the collection, one should also note Paul's thoroughly 'Jewish' theology, soteriology and pneumatology and the references to the Jews / Israel/Jewish Christians in both letters. Many references remind the Gentile Christians of Corinth, Achaia and elsewhere that they have already benefitted tremendously from God's salvation which was primarily intended for his people Israel, into which the Gentile Christians were included.25 Thus there is a Gentile Christian obligation toward Israel. A brief survey has to suffice:

Paul is the apostle of the Jewish Messiah Jesus (1 Cor 1:1). The Corinthians are among those who call on the name of the Lord Jesus Christ (1:2, and many other references to the Christ). Jews and Gentiles both fail in view of God's revelation in Christ crucified (1:22f). The Corinthians therefore have no reason to feel superior (1:26-28). The Gospel had been brought to them by Jewish Christian leaders (1 Cor 1:12; 9:5; all witnesses of the resurrection were Jews, 15.5-8). There is no room for judgment (4:1-4) or arrogance (4:6-13). A number of severe ethical failures even among Gentile Christians deconstruct all claims of superiority over Israel (chapter 5). Paul reminds the readers of their ignominious past (6:9-11). The quotations and references to the Old Testament (see Beale 2007:695-783) show where the authority lies and whose past is relevant to the present. What happened in Israel's past also happened and was written for their instruction (10:1-22). In the language of the Jews, the Christians cry out 'Maranatha' (16:22).

Judea remains an important point of reference for Paul (2 Cor 1:16). Israel saw the glory of God in the face of their God-appointed leader, Moses (3:7, 13-16). The promise in 2 Corinthians 6:16-18 was first given to Israel: they were God's sons and daughters.

Many statements in both letters leave no doubt that, contrary to their own estimate, many Corinthian Christians have little to boast about. Thus, for Gentile Christians, sharing in the widespread anti-Judaism of the ancient world is inappropriate. This must not become an obstacle to wholehearted participation in the collection. What Paul writes to the Romans, namely that the Gentile Christians have a debt to repay to Israel (Rom 15:27), also applies to the Corinthians. ${ }^{26}$

\section{Paul's quarrels with the Corinthians and the presence of opponents}

Paul's detailed description of the Macedonian response indicates that Christians elsewhere fully trust and accept Paul and his apostolic authority and have wholeheartedly joined the collection project. Under the influence of Paul's opponents, the Corinthians are in danger of isolating themselves from the wider Christian community. Paul is by no means a lonely figure: a number of highly recommendable co-workers are involved as well as other churches. These men come as messengers of the churches. The Corinthians' response is before the churches. Paul readily informs the Corinthians about other Christians; he will also inform other Christians about the Corinthians - to their honour or shame.

Space does not permit us to outline in what other ways Paul defended his disputed apostolic status and ministry in both letters in order to re-establish his own integrity and credibility as a leader; for Paul's dealing with his opponents, see Barnett (1993b:646f.) and Georgi (1986); for the defence of his apostolic calling, see Barnett (1993a:49f.).

\section{Paul's financial policy in Corinth}

Paul makes it clear that the collection is not designed to get to the Corinthians' money after all. The same instructions apply to all churches in Paul's sphere of influence. There is a distinct emphasis on transparency: the money will not go to and eventually end up in Paul's pocket. Delegates appointed by the Corinthians will personally deliver the money to the recipients. Whilst for now the donors would have to take Paul's word for it (perhaps questioned by his Judaising opponents), they would eventually see the need

26. In view of the length of Paul's argument in 2 Corinthians 8 . it is noteworthy that Paul does not explain the reasons for the need of the Christians of Jerusalem, either as being the consequence of famine/increased cost of living (see Acts 11:28), of persecution (see 1 Th $2: 14$ ) or of the particular circumstances which earlier on
made the sharing of goods necessary according to Acts $2: 44 f . ; 4: 32-5: 11,6: 1-7$. For now, the Corinthians had to take Paul's word for it. 
in Jerusalem for themselves. In addition to the Corinthians' own delegates, there will be trustworthy independent witnesses regarding the transport and delivery of the collection. Paul is beyond reproach in the matter; he aims at doing right in the sight of God and of people. Elsewhere in both letters Paul explains and defends his past 'financial policy' regarding the Corinthians and the likely attempts of patronage and the dependence it would have implied on his side (for summaries of Paul's financial policy, see Everts 1993; Schnabel 2004:1446-1451; Walton 2011 and the instructive study of Little 2005).

\section{Previous other financial engagement of the Corinthians}

Paul does not address this issue in detail. Paul praises the Corinthians for their previous engagement elsewhere. Due to the inter-church solidarity - an essential aspect of Christian identity - such engagement cannot be limited to one area or period. It must continue and extend. If the Corinthians already shared with other Christians, they should continue to do so and now wholeheartedly join Paul's collection project.

\section{The portrait of Paul the Leader in overcoming the obstacles on the side of the Gentile Christian donors}

Due to the lack of sources, interesting questions regarding the donors and the success of Paul's efforts remain unanswered. Did the Corinthians eventually contribute willingly and according to Paul's instructions? Were they convinced by his arguments? How successful was the ministry of the three men in whom Paul had set his hopes? Whilst Paul tells the Romans that Macedonia and Achaia have been pleased to make some contribution for the poor among the saints at Jerusalem (15:26), the curious fact that the collection delegation mentioned in Acts 20:4 does not include a delegate (or several) from Corinth or Achaia (whilst the other areas of Paul's mission are represented by seven people), may suggest the contrary.

Despite the scarcity of information it is possible to describe what kind of portrait, even if sketchy, emerges from these obstacles and Paul's responses to them of Paul the Leader in the collection enterprise ${ }^{27}$ :

- Despite Paul's insistence on his authority as an apostle of Jesus Christ (in Gal 1:1; 1 Cor 1:1; 2 Cor 1:1; Rom 1:1-5 and elsewhere in the letters which mention the collection), Paul did not and could not simply command participation in the gathering of the collection. In initiating this project and seeing it through, Paul had to employ all his rhetorical skills to win and persuade by speech, in writing and through his co-workers. The collection is a case of

27. For excellent surveys of Paul's understanding of leadership, see Barentsen (2011); Clarke (2000:173-252): Walton (2000). Barentsen examines Paul's strategy of Clarke (2000:173-252); Waton (2000). Barentsen examines Paul's strategy 'Realigning emerging leadership with Christian social identity in 1 Corinthians' (75-111) and Paul's restablishment of his own leadership as a model in Corinthians (112-140). leadership through careful, patient and persistent persuasion based on theology and cultural conventions.

In doing so, Paul adduces the authority of the Jewish Old Testament, refers to the example of Jesus Christ as a model to follow, plays capably on notions of (public) honour and shame and on ancient notions of mutuality and reciprocity, possibly also on the rivalry between cities and regions in antiquity, and he argues with salvation history (the Gentile Christian debt to Jewish Christians). Paul readily bestows recognition and honour on the donors in Macedonia and Corinth for their participation. Paul skilfully places his request of the Corinthians in a wider ecumenical perspective and reminds them that their reputation and recognition in the wider Christian community are at stake, as no church is an island entire to itself.

Paul's rhetoric regarding the collection is to be seen in the wider rhetorical strategy of establishing and defending his disputed apostolic authority; thus the references to the collection must be seen in view of all of Paul's argument 1-2 Corinthians:

- Due to his past strained relationship with the Corinthians and the presence of opponents who sought to undermine his authority and trustworthiness, Paul emphasises full transparency in the matter. The money will definitely not end up in his pocket or be used other than for its intended use. The participating churches will appoint their own delegates to travel with Paul and hand over the sum in Jerusalem themselves. There will be witnesses throughout the whole process, including the actual delivery. These measurements need to be seen in the context of Paul's rhetorical strategy of establishing and defending his own integrity and trustworthiness.

- Paul has thought the matter through carefully and gives clear instructions on how the money is to be collected (1 Cor 16:2) and in what manner it is to be delivered safely to the recipients. He does not leave a project of this importance to chance.

- Paul involves all Christians in Corinth ('each of you', 1 Cor 16:2), not just the wealthy (usually called on for benefaction in Hellenistic contexts). In this way all can and should participate according to their own means and can and will participate in the divine blessing to be expected. The gathering of the collection is to further, not threaten, the unity of individual congregations and the larger church.

- In order to share the work and responsibility, but also to emphasise that the collection is far from a private project of his own, Paul has to, and does, involve a number of people at various levels: the Christians of Galatia, Macedonia and Achaia, his own co-workers, Titus, and two unnamed brothers according to 2 Corinthans 8 , who will assist and oversee the gathering of the collection in Corinth and the delegates which the Corinthians were to appoint (1 Cor 16:3: 'I will send any of you whom you approve ...'). Acts 20:2 lists seven delegates representative of different areas on their way to Jerusalem with Paul. 
Paul passes on responsibility to others ('sending' three men to Corinth) and is willing to take action himself (announcing his own later visit). Paul warmly commends these men and their involvement.

- In recognition of the limits posed by his own person and of strained relationships with the donors in the past, Paul carefully uses and deploys co-workers. There is some realisation that he may be part of the problem.

What does all this tell us about Paul the Leader? In terms and categories of modern leadership theory, the picture which emerges of Paul in these texts is reminiscent of that of a charismatic leader. ${ }^{28}$ The term and concept goes back to the sociologist, Max Weber (1947). In the later discussion of leadership theory this concept has been developed by Robert J. House (1977), House and J.M. Howell (1992) in their essay 'Personality and charismatic leadership' (further contributions by House in the bibliography, p. 105; for House's definitions and critical assessment, see Yukl 1993) and others. House proposed a theory of charismatic leadership in large private and public sector organisations. His theory had the merit of shifting the focus of attention to the leaders' symbolic and expressive behaviour and the expressive behaviour and emotional reactions of followers of the leader and the task (Yukl 1993:367-368). Such leaders are described as endowed with exceptional qualities. According to House's theory:

charismatic leaders have high self-confidence, high verbal ability, high need for influence or power, and exceptionally strong convictions in the moral correctness of their beliefs. Theoretically charismatic leaders need to have a very high degree of self-confidence and moral conviction because their mission is usually unconventional and likely to be resisted from those who have a stake in preserving the status quo. Consequently charismatic leaders need to be exceptionally determined and to persist in the face of high risks and major obstacles. Further, the display of confidence and determination inspires and thus motivates and empowers followers. ${ }^{29}$ (House \& Howell 1992:87 [Author's own italics])

Charismatic leaders rely on appeals to the hopes and ideals of their followers. They have profound and unusual effects on followers, as followers perceive the leader's beliefs to be correct. They accept the leader without question and follow willingly. In addition, they feel affection toward the leader and are emotionally involved in the mission of the group or organisation. Their followers have high performance goals and believe they can contribute to the success of the mission (so Yukl 1993:368; see also House [1976] 1977:191). ${ }^{30}$

\footnotetext{
28.This type of leadership has also been called visionary, transformational of inspirational. A number of methodological issues in applying modern leadership categories to Paul defy any easy and definite identification of one particular or several leadership style(s). In contrast to modern theorising and discussion, no empirical research and verification is possible. Concerning sources, we have only examined the direct collection passages in 1-2 Corinthians (where we had to rely on Paul's assessment of the situation, presented in a highly rhetorical context!) not all of both letters, all of the Corpus Paulinum, nor the portrayal in the Book of Acts.

29. House and Howell (1992:87). The authors provide a summary of research on traits specifically characteristic of charismatic leaders, pp. 86-91.

30.According to House ([1976] 1977:191), the charismatic leader is also implicitly assumed to be an object of identification, by which the followers imitate the leader's values, goals, and behaviour. One of the effects of the charismatic leader, leader's values, goals, and behaviour. One of the effects of the charismatic leader,
'is to cause followers to model their behaviour, feelings and cognitions after the leader'.
}

According to Shamir, House and Arthur (1993), by communicating high performance expectations and at the same time expressing confidence that the followers can attain them ${ }^{31}$, charismatic leaders promote the followers' self-esteem, self-worth, and self-efficacy. They also use role-modelling to symbolise and express new values and to provide an example of exemplary behaviour for followers to imitate (according to the summary of Yukl 1993:369, for a seven point summary of charismatic behaviour, see House \& Howell 1992:83). Obviously not all of these traits identified by sociologists and psychologists will apply to Paul, but this discussion throws an interesting light on our subject.

In Paul's enthusiastic description the Macedonian Christians with their response to the collection appear as the ideal counter-part followers to Paul as charismatic leader. To play on Yukl's description above, according to Paul, the Macedonians perceive Paul's beliefs regarding the necessity of the collection and of their involvement to be correct, accept him without question, obey him willingly and feel affection toward him. They are emotionally involved in the mission of the group (the Gentile Christian churches) as defined by him. They had high performance goals, have met them and believe that they can contribute to the success of the mission. ${ }^{32}$ They are the model to be followed by the Corinthians who still need to be brought into this position (Yukl 1993:368f.).

However, regarding the Corinthians, this characterisation of Paul needs modification: whilst Paul displays some of these traits in his argumentation with the Corinthians regarding their participation in the collection, it is clear that he has to do so as a disputed leader. It was not obvious that (all) the Corinthians will follow him in this or other matters. This was due to the various obstacles which Paul had to overcome in Corinth, including the presence of opponents, opposition in the congregation for various reasons and questions regarding his financial policy. In some aspects, Paul argues like such a charismatic leader, yet he still needs to gain the following of the people he feels in charge of.

According to House (1977:189; see also House \& Howell 1992:87), charismatic leaders frequently represent a break with the established order and accomplish major social changes through their leadership. In demanding that all Corinthians participate in this translocal project of benefaction, Paul asks for a break with the established conventions of benefaction. Whether and to what extent this led to social changes among the donors is difficult to assess.

House (1977:193) describes three personal characteristics of leaders who have charismatic effects: extremely high levels

31.This has also been emphasised by House ([1976] 1977:198): "Leaders who communicate high performance expectations for subordinates and exhibit confidence in their ability to meet such expectations are hypothesised to enhance
subordinates' self esteem and to affect the goals subordinates accept or set for themselves'. However, high expectations only have a positive effect, when the followers perceive the superior to also have confidence in the followers' abilities to meet such expectations.

32.Whether or not Paul's description of the Macedonian response is the whole story we will never know. His earlier praise of the Achaians to the Macdonians (2 Cor 9:2) may suggest that there also might have been another side to the story. 
of self-confidence, dominance, and a strong conviction in the moral righteousness of their beliefs. They also apply to Paul to some extent. With Paul it is a high level of Christ-confidence or self-confidence due to his commission by the risen Lord ('called by the will of God to be an apostle of Christ Jesus', 1 Cor 1:1). He is dominant, if this psychological term is understood as 'a measure of prosocial assertiveness, not a measure of the need to dominate or control others' (House \& Howell 1992:85). And, Paul was certainly convinced about the moral necessity and rightness of the collection enterprise (after all, he risked his own life for it, Rom 15:30-31). When Paul shares his vision of mutual sharing of abundance and supplying the needs of one other (2 Cor 8:13-15) and praise of God, he also scores highly on goal articulation. According to House (1997:197) the first requirement for charismatic leadership is a common shared vision for what the future could be. For Paul the future is a church of Jews and Gentiles characterised by reconciliation and solidarity.

Paul communicates high performance expectations and at the same time expresses confidence that the followers can attain them (2 Cor 8:10-12). To some extent Paul enhances the followers' self-esteem, self-worth and self-efficacy, but he also places them in a wider community in which they are to function. There they are but one pebble on the beach. When appealing to inter-church solidarity and emphasising their identity in the wider Christian community to which the Corinthians belong, Paul betrays a trait which in leadership theory has been identified as characteristic of charismatic leaders, namely that:

People who identify with a group or organisation take pride in being part of it and regard membership as one of their most important social identities. A charismatic leader can increase social identification by providing the group with a unique identity that distinguishes it from other groups and makes it appear special. Specific behaviours to increase social identification include the skilful use of slogans, symbols, rituals, ceremonies, and stories. ... Social identification increases commitment to group objectives by linking the self-concept of individual followers to the shared. (Yukl 1993:369)

In this way, with particular reference to the first obstacle, Paul seeks to 'transform the needs, values, preferences, desires and aspirations of followers from self-interest to collective interests' (House \& Howell 1992:82). His aim is to cause the Corinthians to become again highly committed to his mission, 'to make significant personal sacrifices in the interest of the mission and to perform above and beyond the call of duty' (82) as the Corinthians currently understand it.

Paul uses role-modelling (his own willingness to come along to Jerusalem if necessary, 1 Cor 16:4, the Macedonians' example and, above all, the example of the Lord Jesus Christ who became poor in order to make others rich) to symbolise and express new values and to provide an example of exemplary behaviour for the Corinthians to imitate. It is instructive that Paul does not refer to himself as a model of benefactions to the poor (as e.g. in Gal 2:10, 'only they asked us to remember the poor, the very thing I was eager to do' or Ac 20:34-35), but to the Macedonians' and to Christ's generosity.

Study of Paul as leader along these lines can contribute to alleviating a deficit in the early discussion of charismatic leadership theory, namely the lack of a 'satisfactory explanation of the process by which these leaders are able to influence followers profoundly and motivate them to transcend their own self-interest for the sake of the organisation' (Yukl 1993:368). We have identified some of these processes above. In dealing with the obstacles on the side of the Jewish Christian recipients in Jerusalem and in his willingness to overcome the obstacles which the collection enterprise meant for himself, Paul also appears as a servant leader according to modern categories of leadership (see Greenleaf 1977; addressed in part II). Our short probing into leadership theory indicates that a closer look at Paul provides an instructive historical case study and could contribute to theorising about leadership styles. At the same time, modern leadership theory offers fresh perspectives to the study of Paul as a revered and disputed leader.

There are obvious lessons to be drawn from Paul's leadership in the context of the collection for today's Christian leaders: Christians lead through persuasion, are concerned about transparency, carefully and realistically think their plans and strategies through, involve other people and are willing to bear their share of the burden which they impose on others. How this is to be put into practice will depend on the project, the obstacles that have to be overcome, and the particular larger context in which the task is to be addressed and seen through to its completion. That such leadership might be challenged (at least by some) and will require determination and patience is also clear. A combination of vocation, commitment to Christ and clear vision will sustain Christian leaders in the face of risks, obstacles and hardship.

\section{Acknowledgements Competing interests}

The author declares that he has no financial or personal relationships which may have inappropriately influenced him in writing this article.

\section{References}

Ascough, R.S., 1997, 'Translocal relationships among voluntary associations and early Christianity', Journal of Early Christian Studies 5, 223-241. http://dx.doi. org/10.1353/earl.1997.0054

Barclay, J., 1987, 'Mirror-reading a polemical letter: Galatians as a test case', Journal for the Study of the New Testament 31, 73-93. http://dx.doi. org/10.1177/0142064X8701003105

Barentsen, J., 2011, Emerging leadership in the Pauline mission: A social identity perspective on local leadership development in Corinth and Ephesus, Pickwick, Eugene. (Princeton Theological Monograph Series 168).

Barnett, P.W., 1993a, 'Apostle', in G.F. Hawthorne, R.P. Martin \& D.C. Reid (eds.), Dictionary of Paul and his letters, pp. 45-51, InterVarsity Press, Downers Grove, Leicester.

Barnett, P.W., 1993b, 'Opponents of Paul', in G.F. Hawthorne, R.P. Martin \& D.C. Reid (eds.), Dictionary of Paul and His Letters, pp. 644-653, InterVarsity Press, Downers Grove, Leicester.

Bohak, G., 2010, 'Gentile attitudes toward Jews and Judaism', in J.C. Collins \& D.C. Harlow (eds.), The Eerdmans dictionary of early Judaism, pp. 668-670, Eerdmans, Grand Rapids and Cambridge, UK. 
Carson, D.A \& Moo, D.J., 2005, An introduction to the New Testament, 2nd edn., Zondervan, Grand Rapids.

Clarke, A.D., 2000, Serve the community of the Church: Christians as leaders and ministers, first-century Christians in the Graeco-Roman world, Eerdmans, Grand Rapids, Cambridge.

Chow, J.K., 1992, 'Patronage and power: A study of social networks in Corinth', Journal for the Study of the New Testament S 75, Sheffield Academic Press, Sheffield.

Dickson, J.P., 2003, Mission-commitment in ancient Judaism and in the Pauline communities: The shape, extent and background of early Christian mission, Wissenschaftliche Untersuchungen zum Neuen Testament II.159, Mohr Siebeck, Tübingen.

Downs, D.J., 2006, 'Paul's collection and the Book of Acts revisited', New Testament Studies 52, 50-70. http://dx.doi.org/10.1017/S0028688506000038

Downs, D.J., 2008, The offering of the Gentiles: Paul's collection for Jerusalem and its chronological, cultural and cultic contexts, Wissenschaftliche Untersuchungen zum Neuen Testament II.248, Mohr Siebeck, Tübingen.

Everts, J M., 1993, 'Financial support', in G.F. Hawthorne, R.P. Martin \& D.C. Reid (eds.), Dictionary of Paul and his Letters, pp. 295-300, InterVarsity Press, Downers Grover, Leicester.

Fee, G.D., 1987, The first epistle to the Corinthians, Eerdmans, Grand Rapids. (New International Commentary on the New Testament).

Feldman, L.H., 1993, Jew and Gentile in the ancient world: Attitudes and interaction from Alexander to Justinian, Princeton University Press, Princeton, NJ.

Furnish, V.P., 1984, I/ Corinthians, Doubleday, Garden City. (Anchor Bible 32A).

Garland, D., 2003, 1 Corinthians, Baker, Grand Rapids. (Baker's Exegetical Commentary on the New Testament).

Goldenberg, R., 1979, 'The Jewish Sabbath in the Roman world up to the time of Constantine the Great', in H. Temporini (ed.), Aufstieg und Niedergang der römischen Welt: Geschichte und Kultur Roms im Spiegel der neueren Forschung II.19.1., pp. 430-442, W. de Gruyter, Berlin, New York.

Greenleaf, R.K., 1977, Servant leadership: A Journey into the nature of legitimate power and greatness, Paulist Press, New York.

Gupta, N., 2012, 'Mirror-reading moral issues in Paul's letters', Journal for the Study of the New Testament 34, 361-381. http://dx.doi.org/10.1177/0142064X12442847

Hafemann, S.J., 1993, 'Letters to the Corinthians', in G.F. Hawthorne, R.P. Martin \& D.C. Reid (eds.), Dictionary of Paul and his Letters, pp. 164-179, InterVarsity Press, Downers Grover, Leicester.

Hardin, J.K., 2014, 'Galatians 1-2 without a mirror: Reflections on Paul's conflict with the agitators', Tyndale Bulletin, 65, 275-303.

House, R.J., [1976] 1977, 'Theory of charismatic leadership', in J.G. Hunt \& L.L. Larson (eds.), Leadership: The cutting edge, pp. 189-207, Southern Illinois University Press, Carbondale.

House, R.J. \& Howell, J.M., 1992, 'Personality and charismatic leadership', Leadership Quarterly 3, 81-108. http://dx.doi.org/10.1016/1048-9843(92)90028-E

Hughes, J.T., 2015, 'Ecclesial solidarity in the Pauline Corpus', PhD thesis, School of Divinity, History and Philosophy, University of Aberdeen, Scotland.

Janssen, C. \& Kessler, R., 2009, 'Ehre/Schande', in F. Crüsemann, K. Hungar \& C. Janssen et al. (eds.), Sozialgeschichtliches Wörterbuch zur Bibel, pp. 97-100, Gütersloher, Gütersloh.

Jewett, R., 2007, Romans: A commentary, Fortress, Minneapolis. (Hermeneia).

Kim, B.M., 2002, Die paulinische Kollekte, Texte und Arbeiten zum Newtestamentlichen Zeitalter 38, A. Francke, Tübingen, Basel.

Kim, S., 2011, 'Paul as an eschatological herald', in T.J. Burke \& B.S. Rosner (eds.), Paul as missionary: Identity, activity, theology and practice, Library of New Testament Studies 420, T. \& T. Clark International, London, pp. 9-24.

Lampe, P., 2003, 'Paul, patrons, and clients', in J.P. Sampley (ed.), Paul and the Greco-Roman world: A handbook, pp. 488-523, Trinity Press International, Harrisburg

Little, C.R., 2005, Mission in the way of Paul: Biblical mission for the Church in the twenty-first century, Peter Lang, New York. (Studies in Biblical Literature 80).
Longenecker, B.W., 2010, Remember the poor: Paul, poverty and the Greco-Roman world, Eerdmans, Grand Rapids and Cambridge, UK.

Marshall, J., 2009, Jesus, patrons, and benefactors: Roman Palestine and the Gospel of Luke, Wissenschaftliche Untersuchungen zum Neuen Testament II.259, Mohr Siebeck, Tübingen.

Marshall, P., 1987, Enmity in Corinth: Social conventions in Paul's relations with the Corinthians, Wissenschaftliche Untersuchungen zum Neuen Testament II.23, Mohr Siebeck, Tübingen.

Martin, R.P., 1986, 2 Corinthians, Word Books, Waco (WBC 40).

Matthews, V.H. (ed.), 1996, Honor and shame in the world of the Bible, Semeia 68 , Society of Biblical Literature, Atlanta.

Murphy-O'Connor, J., 1996, Paul: A critical life, Clarendon, Oxford.

Nojima, K., 2011, Ehre und Schande in Kulturanthropologie und biblischer Theologie, Arco, Wuppertal, Wien. (Acro Wissenschaft).

Nongbri, B., 2010, 'Greek Authors on Jews and Judaism', in J.J. Collins \& D.C. Harlow (eds.), The Eerdmans Dictionary of Early Judaism, pp. 692-696, Grand Rapids: Eerdmans.

Plevnik, J., 2000, 'Honour/shame', in B. Malina \& J.J. Pilch (eds.), Handbook of biblical social values, pp. 106-115, Hendrickson, Peabody.

Riesner, R., 1998, Paul's early period: Chronology, mission strategy, theology, Eerdmans, Grand Rapids.

Riesner, R., 2011, 'Pauline chronology', in S. Westerholm (ed.), The Blackwell companion to Paul, pp. 9-29, Wiley Blackwell, Oxford. http://dx.doi. org/10.1002/9781444395778.ch1

Schäfer, P., 1997, Judeophobia: Attitudes toward the Jews in the ancient world, Harvard University Press, Cambridge, MA.

Schnabel, E., 2004, Early Christian mission II: Paul and the early church, Intervarsity Press, Downers Grove; Apollos, Leicester.

Schnabel, E., 2008, Paul, the missionary: Realities, strategies and methods, InterVarsity Press, Downers Grove; Apollos, Nottingham.

Schürer, E., Vermes, G. \& Millar, F., 1973, The history of the Jewish people in the age of Jesus Christ (175 BC-AD 135), vol. I, T. \& T. Clark, Edinburgh.

Shamir, B., House, R.J. \& Arthur, M.B., 1993, 'The motivational effects of charismatic leadership: A self-concept theory, Organization Science 4, 1-17. http://dx.doi. org/10.1287/orsc.4.4.577

Stenschke, C., 1999, Luke's portrait of Gentiles prior to their coming to faith Wissenschaftliche Untersuchungen zum Neuen Testament II.108, Mohr Siebeck, Tübingen.

Stenschke, C., 2011, “"Not the only pebble on the beach": The significance and function of Paul's references to Christians other than the addressees in 1 and 2 Corinthians', Neotestamentica 45, 331-357.

Walker, W.O., 2011, 'Apollos and Timothy as the unnamed "brothers" in 2 Corinthians 8:18-24', Catholic Biblical Quarterly 73, 318-338.

Walton, S., 2000, Leadership and lifestyle: The portrait of Paul in the Miletus speech and 1 Thessalonians. Cambridge University Press, Cambridge. (Society for New Testamentical Studes. MS 106). http://dx.doi.org/10.1017/CBO9780511488191

Walton, S., 2011, 'Paul, patronage and pay', in T.J. Burke \& B.S. Rosner (eds.), Paul as missionary: Identity, activity, theology, and practice, pp. 220-233, T. \& T. Clark, London. (Library of New Testament Studies 420).

Weber, M., 1947, The theory of social and economic organisations, New York, Free Press.

Wenham, D., 1993, 'Acts and the Pauline corpus II. The evidence of parallels', in B.W. Winter \& A.D. Clarke (eds.), Ancient literary setting, The Book of Acts in its first century setting 1, pp. 215-258, Eerdmans, Grand Rapids; Paternoster, Carlisle.

Williams, M.H., 2010, 'Latin authors on Jews and Judaism', in J.C. Collins \& D.C. Harlow (eds.), The Eerdmans dictionary of Early Judaism, pp. 870-874, Eerdmans, Grand Rapids and Cambridge, UK.

Yukl, G., 1993 'A retrospective on Robert House's 1976 "Theory of charismatic leadership" and recent revisions', Leadership Quarterly 4, 367-375. http://dx.doi. org/10.1016/1048-9843(93)90041-Q 